九州大学学術情報リポジトリ

Kyushu University Institutional Repository

Notes on the Genus Balclutha (Hemiptera:

Auchenorrhyncha: Cicadellidae) in Indonesia

Kamitani, Satoshi

Ubaidillah, Roshichou

Kahano, Sih

Herwint, Simbolon

他

https://doi.org/10.5109/2703

出版情報 : ESAKIA. 45，pp.61-67，2005-03-31. Entomological Laboratory，Faculty of Agriculture， Kyushu University

バージョン :

権利関係 : 
ESAKIA, (45): 61-67. March 31, 2005

\title{
Notes on the Genus Balclutha (Hemiptera: Auchenorrhyncha: Cicadellidae) in Indonesia ${ }^{1)}$
}

\author{
Satoshi Kamitani \\ Entomological Laboratory, Faculty of Agriculture, Kyushu University, \\ Fukuoka, 812-8581 Japan \\ Rosichon UBAIDILLAH, Sih KAHONO \\ Museum Zoologicum Bogoriense, Zoological Division, Research Center for Biology, \\ Indonesian Institute of Science, Cibinong, 16911 Indonesia \\ Simbolon HerWINT and Tulkirin PARTOMIHARDJO \\ Herbarium Bogoriense, Botanical Division, Research Center for Biology, \\ Indonesian Institute of Science, Bogor, 16122 Indonesia
}

\begin{abstract}
Additions to the Indonesian Balclutha fauna were made after, the following two species and one species complex were newly recorded for Indonesia: $B$. noonadana, $B$. rubrinervis, and the $B$. sternalis complex. Balclutha cheesmanae, whose type localities are Java and Papua New Guinea, was recorded from Sulawesi for the first time. Although no Balclutha species had been known from the Krakataus, $B$. lucida was newly recorded for Anak Krakatau. Since a species similar to $B$. lucida can migrate long distances, $B$. lucida may also have migrated to this island. Though there are three islands in the Krakataus, B. lucida was found only on the youngest island. The host grasses of this species were abundant on the Anak Krakatau, the youngest island, but they are not abundant on the other islands. An establishment of this species on Anak Krakatau is related to floral succession and this Balclutha species may face extinction if floral succession progresses on this island.
\end{abstract}

Key words: New distributional records, Balclutha, Indonesia, Krakatau Islands, Java, Sulawesi.

1) Contribution from the Entomological Laboratory, Faculty of Agriculture, Kyushu University, Fukuoka (Ser. 6, No. 12). 


\section{Introduction}

The cosmopolitan genus Balclutha Kirkaldy, 1900, belongs to the tribe Balcluthini Baker, 1915 of the subfamily Deltocephalinae (Oman et al., 1990. This grass-feeding leafhopper genus is abundant in the tropics, and 25 species and two species complexes were recognized from the Oriental region (Webb \& Vilbaste, 1994). Fifteen species of Balclutha are known from Indonesia (Webb \& Vilbaste, 1994; Fletcher, 2004). They are B. alstoni Knight, 1987, B. bacchusi Knight, 1987, B. bifasciata (Merino, 1936), B. cheesmanae Knight, 1987, B. chloroptera Melichar, 1914, B. distenda Knight, 1987, B. flagellata Knight, 1987, B. incisa (Matsumura, 1902), B. lucida (Butler, 1877) , B. pseudorosea Knight, 1987, B. rieki Knight, 1987, B. rosea (Scott, 1876), B. saltuella (Kirschbaum, 1868), B. simplex Knight, 1987, and $B$. viridinervis (Matsumura, 1914). In addition to the former 15 species, it was expected that the following three Balclutha species would occur in Indonesia on the basis of their known distributional ranges (Webb \& Vilbaste, 1994): B. noonadana Knight, 1987, B. rubrinervis (Matsumura, 1902), and B. rubrostriata (Melichar, 1903).

Three field surveys of the auchenorrhynchan fauna were performed in Indonesia; Gunung Halimun National Park in west Java, Sampurage - Soroako in central Sulawesi, and the four islands in the Krakatau Islands. Gunung Halimun National Park is the largest sub-mountain forest remaining on the island of Java. Host plants of Balclutha, poacean grasses, are not abundant in this park because the annual rainfall exceeds $4,000 \mathrm{~mm}$. Even though the habitat in this park is not suitable for habitation by grass-feeding leafhoppers, three Balclutha species were collected near rice fields. Sampurage and Soroako are covered with secondary submountain forest. We collected two Balclutha species and one species complex from these areas. The Karakatu Islands in the Sunda Strait consist of four islands: Rakata, Panjang, Sertung, and Anak Krakatau. The flora and fauna of the first three islands were damaged significantly by the catastrophic 1883 volcanic eruption of Krakatau Island. In constrast, Anak Krakatau rose above the sea in the 1930 s as a result of submarine eruption. Although many field surveys of the flora and fauna were performed after the eruption, no species of Balclutha had been recorded. However, we found a species of Balclutha, but only from Anak Krakatau.

\section{Materiall and Methods}

Leafhoppers were randomly swept by Satoshi Kamitani in the following regions: Gunung Halimun National Park for 15 days on 7-21 August 1997, Sulawesi for 16 days on 8-23 October 1999, Rakata for five days on 9-13 October 2000, Panjang for a half day on 13 October 2000, Sertung for a half day on 12 October 2000, and Anak Krakatau for a half day on 12 October 2000. 


\section{Distributional Record}

\section{Balclutha lucida (Butler, 1877)}

Material examined. [Java] $4 \sigma^{\nearrow} 1$ 우, Cikaniki (alt. 900m), Gunung Halimun National Park, 7. viii. 1997, S. Kamitani; $8 \sigma^{\top} 6$ 우, same data except 12. viii. 1997; $4 \sigma^{\top} 3$ 우, same data except

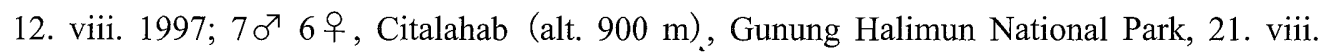
1997, S. Kamitani. [Krakatau Isls.] $10^{\nearrow}$, Anak Krakatau Is., 12. x. 2000, S. Kamitani.

Remarks. This species is distributed widely in the Australian, W. Pacific, Ethiopian, Nearctic, Neotropical, and Oriental Regions. Although eight cicadellid species were recorded from the Krakatau Isls. (Dammerman, 1922), the collection of Balclutha lucida is a new record from this island.

\section{Balclutha noonadana Knight, 1987}

Material examined. [Java] $35 \sigma^{7} 27$ 우, Cikaniki (alt. 900m), Gunung Halimun National Park, 8. viii. 1997, S. Kamitani; $13 \sigma^{\top} 4$ 우, same data except 12. viii. 1997; $15 \sigma^{\nearrow} 9$ 우, same data except 22. viii. 1997; 1 우, Cikaniki - Citalahab (alt. 950m), Gunung Halimun National Park, 16. viii. 1997, S. Kamitani.

Remarks. Balclutha noonadana has only been recorded from the Indian subcontinent, the Philippines, and Bismark Is., localities which are quite distant from each other. Webb \& Vilbaste (1994) therefore expected that Balclutha noonadana should be distributed in Indonesia. We found this species on Java, and this is the first record of this species in Indonesia.

\section{Balclutha rubrinervis Matsumura, 1902}

Material examined. [Java] $21 \sigma^{\nearrow 12}$ 우, Cikaniki (alt. 900m), Gunung Halimun National Park, 7. viii. 1997, S. Kamitani; $7 \sigma^{\nearrow} 7$ 우, same data except 12. viii. 1997; $2 \sigma^{\nearrow} 1$ 우, same data except 22. viii. 1997; $10^{7} 1$ 우, Gunung Botol, Gunung Halimun National Park, 7. viii. 1997, S. Kamitani.

Remarks. Balclutha rubrinervis was widely distributed in the East Palaearctic Region and Knight (1987) reported that it occurred in Vanuatu. Webb \& Vilbaste (1994) therefore expected that it should be distributed in Indonesia. We found this species on Java, and this is the first record of this species in Indonesia.

\section{Balclutha cheesmanae Knight, 1987}

Material examined. [Sulawesi] 10 , Sanpurage (alt. 800m), near Mangkutana, 19. x. 1999, S. Kamitani; $1 \delta^{\top} 1$ 우, Sanpurage (alt. 600m), near Mangkutana, 20. x. 1999, S. Kamitani; $10^{\pi}$, Soroako - Leduladu (alt. 630m), 21. x. 1999, S. Kamitani.

Remarks. Although the type locality of this species is Java and Papua New Guinea, this is 
the first record of this species from Sulawesi.

Balclutha chloroptera Melichar, 1914

Material examined. [Sulawesi] $7 \sigma^{\top} 5$ 우, Sanpurage (alt. 600m), near Mangkutana, 20. x. 1999, S. Kamitani.

\section{Balclutha sternalis (Distant, 1918) complex}

Material examined. [Sulawesi] $13 \sigma^{\nearrow} 4$ 우, Soroako - Leduladu (alt. 630m), 21. x. 1999, S. Kamitani.

Remarks. This taxonomically very difficult species complex is distributed in Russia, India, China, and Nepal. This is the first record of members of this species complex from Indonesia. The shape of the aedeagus collected in Indonesia (Figs. 1-6) is different from that of species found in Russia, India, and China (Fig. 7, left), but it is very similar to that of species found in Nepal (Fig. 7, right).

\section{Discussion on finding Balclutha on the Krakatau Islands}

In the long-distance migration of Auchenorrhyncha, that of Nilaparvata lugens (Stål, 1854) (Delphacidae) is the most famous (Taler, 1985). However, a case of long-distance migration involving Balclutha saltuella (Kirschbaum, 1868) was observed on Ascension Island in the tropical Atlantic (Ghauri, 1983). This species is thought to migrate over 1,000 km. Balclutha lucida found on the Krakatau Isls. has two similarities with B. saltuella: 1) its host plant is poacean grasses, and 2) the distributional range is very wide (Wilson \& Claridge, 1991). Therefore, it ought to be easy for B. lucida to migrate from Java or Sumatra to the Krakataus. Since nine of the ten butterfly species on the Krakatau Isls. consisted of Javanese subspecies (Yukawa, 1984), B. lucida might be able to migrate from Java.

Balclutha lucida was found only on Anak Krakatau and was not found on the other three islands, all of which are older than Anak Krakatau. This island is very young and a forest has not developed yet. In contrast, Rakata, Sertung, and Panjang are now covered with a forest. Significantly, the host poacean grasses of B. lucida are very abundant only on Anak Krakatau and B. lucida was found only on Anak Krakatau. However, the leafhopper will disappear from Anak Krakatau, if the forest develops on this island.

\section{Acknowledgements}

We would like to express our sincere thanks to Prof. O. Tadauchi (Kyushu University) for his review of an earlier draft. We are also indebted to Prof. Emeritus J. Yukawa (Kyushu University) and Prof. M. Hayashi (Department of Biology, Faculty of Education, Saitama 

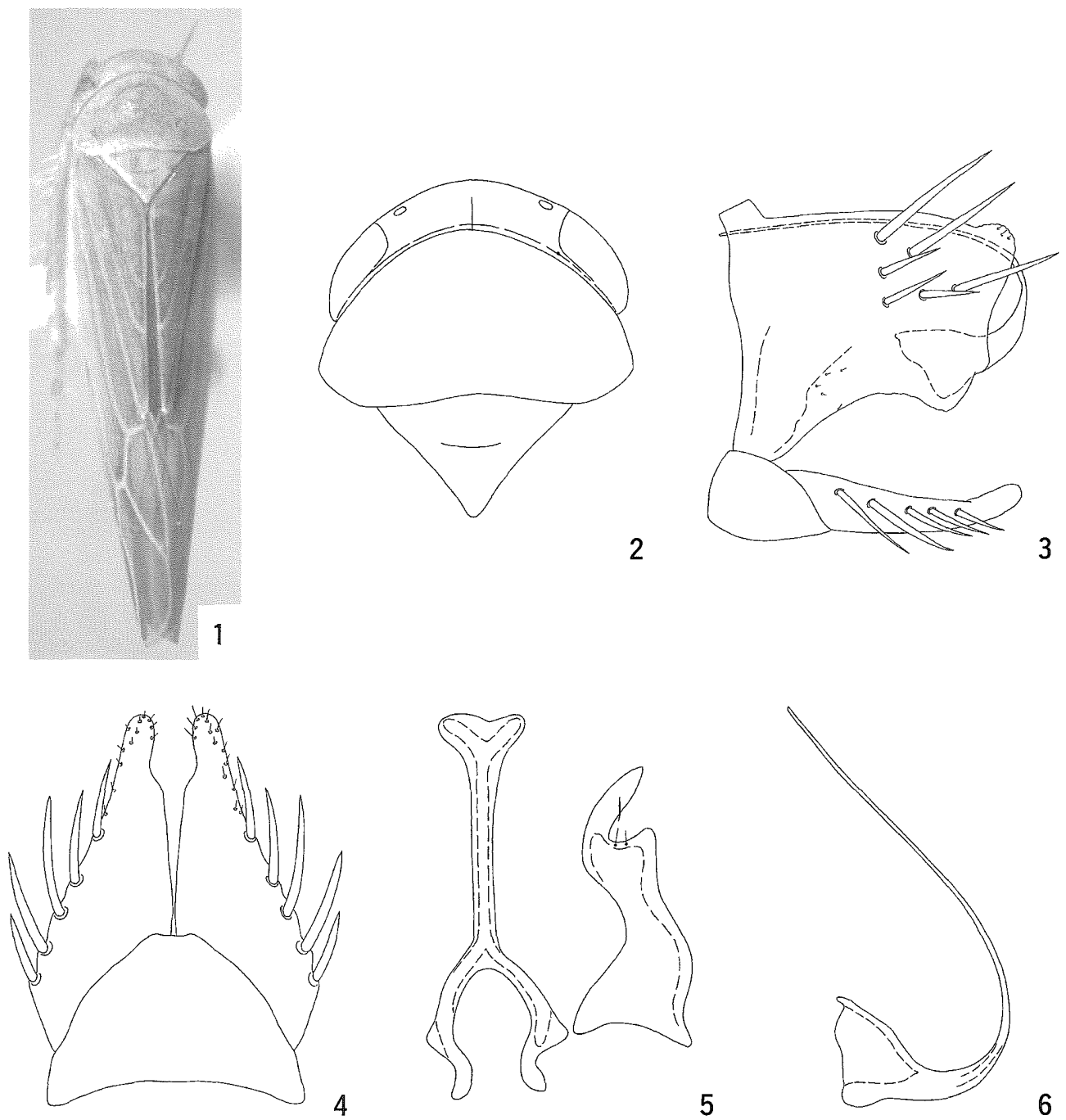

Fig. 1-6. Balclutha sternalis complex, $\sigma^{\top} .1$, dorsal habitus; 2, head, pronotum and mesonotum in dorsal view; 3, pygofer in lateral view; 4, genital plates and valve in ventral view; 5 , styles and connective in dorsal view; 6 , aedeagus in lateral view.

University) for offering useful information, and to Dr. N. Maryana (Department of Plant Pests and Diseases, Faculty of Agriculture, Bogor Agricultural University), and Dr. W. A. Noerdjito (Museum Zoologicum Bogoriense, Zoological Division, Research Center for Biology, Indonesian Institute of Science) for help during our field surveys. 


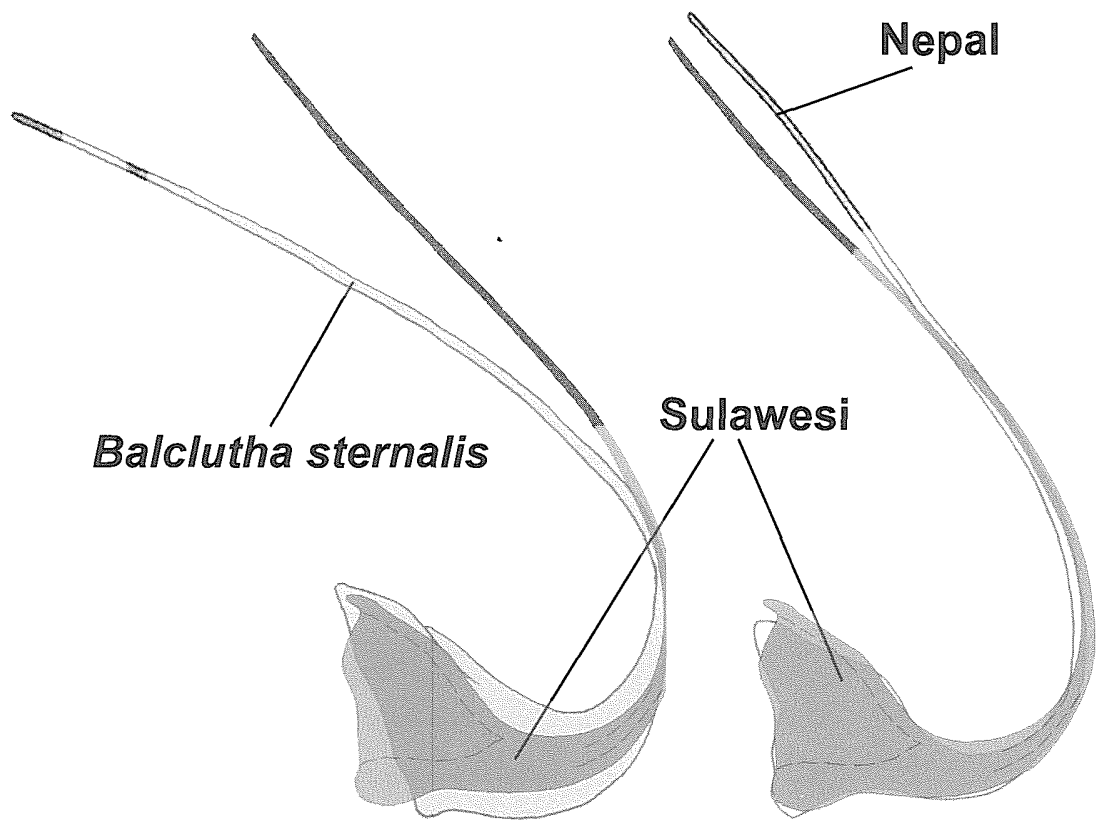

Fig. 7. Diagnostic comparison of aedeagal shapes of Balclutha sternalis complex.

Left: comparison between aedeagi of Balclutha sternalis and a specimen from Sulawesi; right: comparison between aedeagi of specimens from Sulawesi and Nepal.

\section{References}

Dammerman, K. W., 1922. The fauna of Krakatau, Verlaten Island and Sebesy. Treubia, 3: 61-112.

Fletcher, M. J., 2004. Identification Key and Checklists for the Leafhoppers and Treehoppers of Australia and Neighboring Areas (Hemiptera: Cicadellidae, Eurymelidae, Membracidae). Key and checklist published at http://www.agric.nsw.gov.au/Hort/ascu/ leafhop/cica0.htm.

Ghauri, M.S.K., 1983. A case of long distance dispersal of a leafhopper. In Knight, W. J., N. C. Pant, T. S. Robertson \& M. R. Wilson (eds.), First International Workshop on Leafhoppers and Planthoppers of Economic Importance, pp. 249-255. Commomwealth Inst. Entomol., London.

Knight, W. J., 1987. Leafhoppers of the grass-feeding genus Balclutha (Homoptera, Cicadellidae) in the Pacific Region. J. nat. Hist., 21: 1173-1224.

Oman, P. W., W. J. Knight \& M. W. Nielson, 1990. Leafhoppers (Cicadellidae): A 
Bibliography, Generic Checklist and Index to the World Literature 1956 - 1985. $368 \mathrm{pp}$. C. A. B. Int. Inst. Entomol., Oxon.

Taler, R. A. J., 1985. Migratory behavior in the Auchenorrhyncha. In Nault, L. R. \& J. G. Bordriguez (eds.), The Leafhoppers and Planthoppers, pp. 259-288. John Wiley \& Sons, New York.

Webb, M. D. \& J. Vilaktamath, 1994. Review of the leafhopper genus Balclutha Kirkaldy in the Oriental Region (Insecta: Homoptera: Auchenorrhyncha: Cicadellidae). Entomol. Abh. Mus. Tierkd. Dresden, 56: 55-87.

Wilson, M. R. \& M. F. Claridge, 1991. Handbook for the Identification of Leafhoppers and Planthoppers of Rice. CAB international, Oxon.

Yukawa, J., 1984. Geographical ecology of the butterfly fauna of the Krakatau Islands, Indonesia. Tyo to $G a, 35:$ 47-74. 
